\section{Environmental stewardship}

\author{
R. J. Berry
}

Caring for Creation: An Ecumenical Approach to the Environmental Crisis. By Max Oelschlaeger. Yale University Press: 1994. Pp. 285. \$35, £22.50.

The Earth, Humanity and God. By Colin A. Russell. UCL Press: 1994. Pp. 193. $£ 30$ (hbk); $£ 9.95$ (pbk).

MAX Oelschlaeger is an environmental philosopher at the University of North Texas, best known for his valuable study of the Idea of Wilderness (Yale University Press, 1991). He begins his new book with a profession of conversion: that he had been wrong to trust in the "experts" who claimed to be able to "manage planet Earth" and that he had been mispersuaded by Lynn White's influential essay on "the historical roots of our ecological crisis", published in Science in 1967, about the culpability of JudaeoChristianity for environmental problems. $\mathrm{He}$ is encouraged by international agreements on environment cooperation, but judges that politicians are too narrowminded and technologists too powerless to take effective action. (He quotes the Agenda of Science for Environment and Development into the Twenty-First Century (ASCEND) Conference of the International Council of Scientific Unions (IUCN) in Vienna, which shaped the Agenda 21 at the United Nations Conference on Environment and Development in 1992, and the joint declaration of the Royal Society of London and the US National Academy of Science, which urged action on such problems as population, climate warming and biodiversity.)

Oelschlaeger's indictment of the environmental record of politicians is well worn, but needs reading into the record of all aspirants. For example: "issues of ecological consequence are not parceled out in terms of political office" (identified as lasting $4 \pm 2$ years); the 1980 s represented "the Reagan antienvironmental revolution"; gross national product is "a truncated, obsolete and increasingly unworkable measure of the economy"; and "competition undercuts voluntary cooperation across firms". He quotes the US vice-president, Al Gore: "emphasis on the rights of the individual must be accompanied by a deeper understanding of the responsibilities to the community that every individual must accept if the community is to have any organizing principle at all." His conclusion is that only religion offers a viable and neutral forum to produce the necessary commitments on lifestyle, resource use and discipline.

Although he acknowledges his debt to

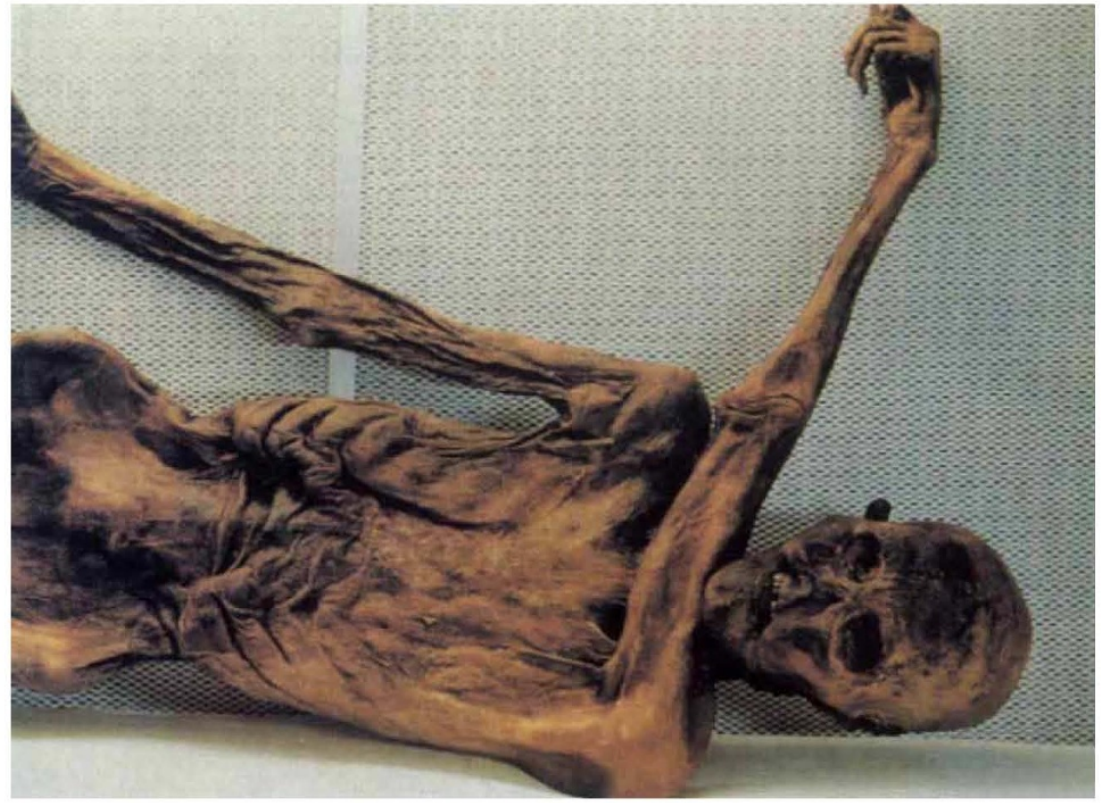

THE discovery in 1991 of this mummified Neolithic man in an alpine glacier on the Austrian-Italian border attracted widespread attention. But the delay in publication of detailed information about the body and its associated finds led to nagging doubts about the iceman's authenticity (see Commentary in Nature 362, 11; 1993). These rumours are now laid to rest with the results of DNA tests, reported in last week's issue of Science, as well as with the recent publication of The Man in the Ice by Konrad Spindler, one of the first archaeologists to investigate the body. The book, from which this picture is taken, claims to provide "the fullest picture yet" of the discovery. Weidenfeld and Nicolson, £18.99.

Francis Schaeffer's Pollution and the Death of Man (Hodder and Stoughton, 1970), which was itself a response to White's article, Oelschlaeger's ecumenical vision is almost entirely atheological. He speaks about skyhooks ("privileged metaphysical claims of religions") and religious toeholds (an acknowledgement of "a sacred canopy or ultimate belief that frames the world"), but he is really concerned with a medium for nonsectarian dialogue. This is an odd claim to make for religions, but possible in the North American ethos, which is Oelschlaeger's specific context. His argument is that four institutions (state, corporation, university and church) "shape social and natural ecology", but only the church is outside the competitive grudges stimulated by monetarization. Furthermore, the church is involved because "our ethical and political lives are collapsing as [the result of] the unbridled pursuit of a narrowly defined and scientifically tenuous conception of economic success".

There are people who will disagree with this diagnosis and prognosis about the structure of society, but they are mainly those outside the scientific community or who have a vested interest in the status quo. The proposal that the church provides a way forward is even more contentious; here it has to be recognized that Oelschlaeger's prescription is specifically directed towards the North American situation. But his general point about the gap between environmental problem and environmental response is wholly valid. (I am referring here to rationally directed scientific response, rather than the excited, sincere but sadly random reaction of 'concerned citizens'.) An excellent cautionary tale (not recorded by Oelschlaeger) is the World Conservation Strategy (International Union for the Conservation of Nature/Worldwide Fund for Nature/United Nations Environment Programme). This was a clearly argued case for sustainable development through careful conservation, but fell heavily into the Enlightenment fallacy that rationality is inseparable from response. Through the perspicacity of Max Nicholson, the Conservation and Development Programme for the UK (Kogan Page, 1983) contained a substantial section on ethics, emphasizing the importance of personal and corporate value as an essential component and stimulus of commitment. In 1986, the IUCN (the main author of the strategy) recognized the omission in the original document, and set up an ethics working group. This contributed significantly to the revised strategy, Caring for the Earth (1991).

Other agencies have responded similarly. The G7 nations held a conference on environmental ethics in 1989 and agreed on the need for responsible stewardship; the following year they produced a "Code 